\title{
Role of pockmarks in diversity and species assemblages of coastal macrobenthic communities
}

\author{
Stanislas F. Dubois ${ }^{1, *}$, François Dérian ${ }^{1}$, Xavier Caisey ${ }^{1}$, Carinne Rigolet $^{1,2}$, \\ Jean-Claude Caprais ${ }^{3}$, Eric Thiébaut ${ }^{2,4}$ \\ ${ }^{1}$ Laboratoire Ecologie Benthique, Dynamiques de l'Environnement Côtier (DYNECO), Institut Francais de Recherche \\ pour l'Exploitation de la Mer (Ifremer), Technopole Brest-Iroise, BP 70, 29280 Plouzané, France \\ ${ }^{2}$ Sorbonne Universités, Université Pierre et Marie Curie/Université Paris 06, Unité Mixte de Recherche 7144, \\ Adaptation et Diversité en Milieu Marin, Station Biologique de Roscoff, 29680 Roscoff, France \\ ${ }^{3}$ Département Etude des Ecosystèmes Profonds (DEEP), Institut Francais de Recherche pour l'Exploitation de la Mer \\ (Ifremer), Technopole Brest-Iroise, BP 70, 29280 Plouzané, France \\ ${ }^{4}$ Centre National de la Recherche Scientifique (CNRS), Unité Mixte de Recherche 7144, Adaptation et Diversité en Milieu Marin, \\ Station Biologique de Roscoff, Place Georges Teissier, 29680 Roscoff, France
}

\begin{abstract}
We used existing bathymetric data to study the macrofauna of a geophysical pockmark field restricted to a benthic habitat engineered by the tubiculous amphipod Haploops nirae in South Brittany (France). Stations inside and outside pockmarks of different morphometric characteristics (location, size, depression depth) were sampled for macrofauna and environmental parameters (sediment characteristics, organic matter, chl $a$, hydrogen sulfide and methane concentrations). Diversity indices showed higher species richness inside pockmarks, especially for species with medium to high abundances. Most sediment cores showed low methane but high hydrogen sulfide concentrations. We hypothesised that after eruption, the remaining residual methane from pockmark sediments is oxidised by seawater sulfate and accounts for the high sulfide concentrations found at increasing depth in our samples and the low methane concentrations. We found no relationship between sediment profiles and morphometric features of the pockmarks. Macrofauna assemblages inside vs. outside pockmarks appeared to be different. Pockmarks appear to increase connectivity among habitats and heterogeneity within habitats, thereby creating local hotspots that allow the settlement of species that cannot otherwise develop in Haploops tube mats. Multivariate analyses distinguished 4 groups of pockmarks and control stations. We assumed that deeper pockmarks were created more recently than shallow pockmarks and that each pockmark is at a different stage of evolution, hence explaining the large variability in the characteristics of pockmark groups. This explains why previous investigations have found contradictory results when comparing macrofauna species diversity and composition between areas inside and outside pockmarks. Finally, we propose and discuss a successional stage model for pockmarks.
\end{abstract}

KEY WORDS: Benthic habitat · Biodiversity · Succession · Amphipod · Haploops · South Brittany · Sulfide $\cdot$ Methane $\cdot$ Environmental factors

Resale or republication not permitted without written consent of the publisher

\section{INTRODUCTION}

Pockmarks are circular or ellipsoidal depressions in the seabed formed by a variety of geophysical mechanisms. They commonly result from an expulsion of gas (methane seeping) or liquid (coastal groundwater) through the seafloor sediment in response to seismic activity, sediment compaction or tidally driven hydraulic pumping (Hovland \& Judd 1988). Pockmarks are one of the most widespread topo- 
graphic features of the seabed. They were first reported on the Nova Scotian shelf (Canada) (King \& MacLean 1970) and have been found almost everywhere in the world since then (Hovland \& Judd 1988). Other marine areas where pockmarks have been extensively surveyed are the eastern Canadian continental shelf (Fader 1991, Wildish et al. 2008), the central North Sea (Dando et al. 1991, Gafeira et al. 2013) and the Norwegian continental slope (Hovland 2005, Webb et al. 2009c). Pockmarks are usually found in muddy or muddy sand sediments at depths ranging from less than $10 \mathrm{~m}$ in estuarine areas (Garcia-Gil et al. 2002) to over $3000 \mathrm{~m}$ in deep offshore canyons (Olu et al. 2009). There is an overall relationship between the size of the pockmarks and the depth at which they are found. Mega (or giant) pockmarks are found in deeper locations and have been reported to range from 500 to $1000 \mathrm{~m}$ in radius, for example off the southwestern African coast (OluLeroy et al. 2007, Pilcher \& Argent 2007). Smaller pockmarks are usually 10 to $50 \mathrm{~m}$ wide and are found in shallow coastal waters (around $30 \mathrm{~m}$ ), such as in the Oslofjord (Norway) (Hovland 2005, Webb et al. 2009c). Intermediate sizes are found off coasts along the continental slope (Sorbe et al. 2010).

Recent advances in the performance of acoustic techniques such as side-scan sonars and multibeam echosounders and their increased use have improved mapping of benthic habitats and knowledge of associated seabed features, including pockmark fields (Brothers et al. 2011). While giant pockmarks are usually isolated (Dando et al. 1991, Pilcher \& Argent 2007), pockmarks in coastal areas have been shown to have either low densities (e.g. about 2 pocks km${ }^{-2}$, or 500 pockmarks altogether, in the $179 \mathrm{~km}^{2}$ of the inner Oslofjord, Norway) (Webb et al. 2009c) or higher densities of about 200 pocks $\mathrm{km}^{-2}$ in Belfast Bay (United Kingdom) (Hovland \& Judd 1988, Kelley et al. 1994). To our knowledge, the highest densities of pockmarks found to date are those discovered in muddy sediments of South Brittany (France), where up to 2500 pocks km${ }^{-2}$ were recorded (Baltzer et al. 2014).

Pockmarks have mainly been studied from geological and geophysical perspectives to understand and predict the conditions necessary for the formation and maintenance of these seabed features (Hovland et al. 2010, Brothers et al. 2011). However, biological investigations of the marine diversity associated with pockmarks are far less abundant. In deep sea environments (over $1000 \mathrm{~m}$ depth), a few studies using remotely operated vehicles have characterized fauna associated with actively seeping pockmarks.
They often reported large Beggiatoa bacterial mats (Decker et al. 2012) and chemosynthesis-based macrobenthic (Menot et al. 2010) and meiobenthic (Zeppilli et al. 2012) species assemblages influenced directly or indirectly by methane seeping. In shallower coastal systems (depths up to $100 \mathrm{~m}$ ), the pioneer investigation of a single large active pockmark in the North Sea also revealed a specific benthic species assemblage composed of the bivalve Thyasira sarsi and the gutless nematode Astomonema sp., both of which contain endosymbiotic bacteria (Dando et al. 1991). The only 2 extensive and comprehensive investigations of shallow pockmark fields to date were carried out in Passamaquoddy Bay (Canada) (Wildish et al. 2008) and in the inner Oslofjord (Norway) (Webb et al. 2009a,c). Both studies revealed small and subtle differences in macrobenthic assemblage composition between areas inside and outside the pockmarks. In the Oslofjord, regional environmental and pollution gradients made observed differences difficult to assign to pockmark effects (Webb et al. 2009a). Nevertheless, these authors showed that pockmarks acted as refuges for marine megabenthic biodiversity and provided shelter from trawling activity, as indicated by occurrences of methane-derived authigenic carbonates colonized by diverse and abundant slow-growing corals.

In the Bay of Concarneau (South Brittany, France), recent investigations using sonar and seismic profiles have indicated the presence of a large pockmark field covering a well-delimited area of $36 \mathrm{~km}^{2}$ in water depths ranging between 20 and $40 \mathrm{~m}$ (Baltzer et al. 2014). While pockmark densities here vary from less than 1000 to $2500 \mathrm{~km}^{-2}$, their sizes range from less than 1 to about $35 \mathrm{~m}$, with depths rarely exceeding $2 \mathrm{~m}$. The pockmark field is located above a palaeovalley system and is restricted to a muddy benthic habitat engineered by the amphipod species Haploops nirae (Ehrhold et al. 2006, Baltzer et al. 2014). H. nirae (hereafter referred to as Haploops) is a gregarious tubiculous organism that builds extensive mats in shallow muddy habitats. Haploops communities can only develop where sediment-hydrodynamic conditions are suitable, and the tubes they occupy cause significant interactions between animals and the physical environment (Wildish \& Dickinson 1982, Rigolet et al. 2011). The fauna associated with the Haploops community was revealed to be more speciose than the fauna in surrounding benthic habitats, with $70 \%$ of species only found in the Haploops habitat (Myers et al. 2012, Rigolet et al. 2012, 2013). In this context, the main question we addressed in the present study was 

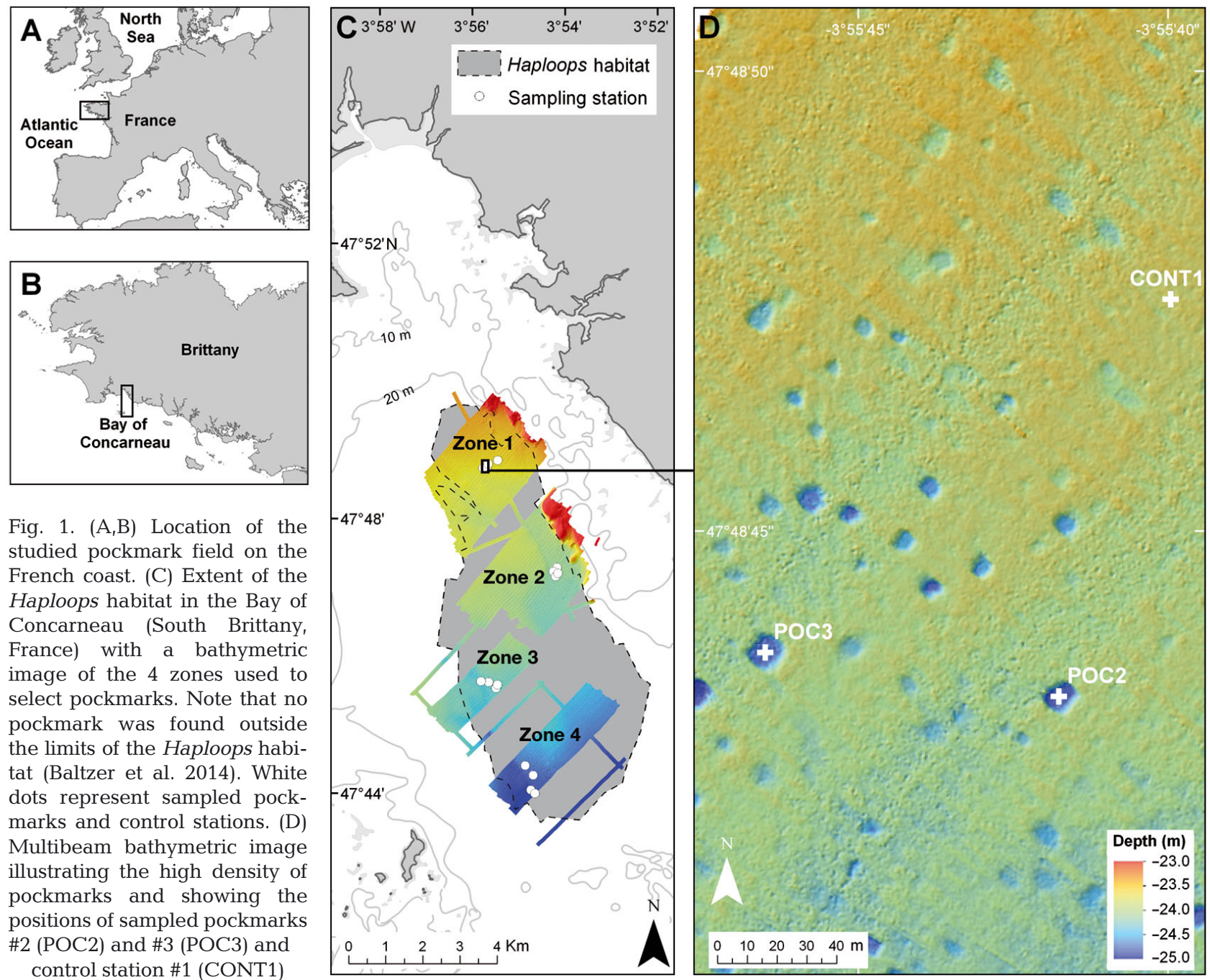

Fig. 1. $(\mathrm{A}, \mathrm{B})$ Location of the studied pockmark field on the French coast. (C) Extent of the Haploops habitat in the Bay of Concarneau (South Brittany, France) with a bathymetric image of the 4 zones used to select pockmarks. Note that no pockmark was found outside the limits of the Haploops habitat (Baltzer et al. 2014). White dots represent sampled pockmarks and control stations. (D) Multibeam bathymetric image illustrating the high density of pockmarks and showing the positions of sampled pockmarks \#2 (POC2) and \#3 (POC3) and control station \#1 (CONT1)

whether the composition of the benthic macrofauna community differed between inside and outside pockmarks and, if so, in what way. We examined a sample of pockmarks and recorded numerous morphological characteristics (e.g. depth, size, location) and environmental parameters (e.g. granulometry, organic matter, methane and hydrogen sulfide $\left(\mathrm{H}_{2} \mathrm{~S}\right)$ concentrations) with the objective of explaining the variability of species assemblages found inside pockmarks and inferring their role in local and regional diversity and in the functioning of benthic habitats. In light of the results obtained, we discuss the relationship between the relative age of pockmarks and associated fauna that has colonized them and use all relevant biotic and abiotic information collected to create a model of pockmark successional stages.

\section{MATERIALS AND METHODS}

\section{Study site}

Pockmarks were sampled in the Bay of Concarneau, South Brittany, in the northern part of the Bay of Biscay, France $\left(47^{\circ} 48^{\prime} \mathrm{N}, 03^{\circ} 54^{\prime} \mathrm{E}\right)$ (Fig. 1A-C). Several thousand pockmarks have recently been mapped in this area of $36 \mathrm{~km}^{2}$ (Baltzer et al. 2014). This bay resembles many coastal embayments in Brittany because it is sheltered by a succession of rocky islets and is characterized by soft-bottom substrates, spanning from mud to muddy sand, with depths ranging from 15 to $35 \mathrm{~m}$ (Ehrhold et al. 2006). The westernmost part (northern Mouton islets and Glénan Islands) is composed of Owenia fusiformis and Amphiura filiformis muddy sands 
and sandy muds. The central part of the bay, where currents are considerably lessened, is composed of pure mud supporting a dense population of the tubiculous amphipod Haploops nirae (Fig. 1D). The western edges of the Haploops habitat are surrounded by patchy Sternaspis scutata muddy sediments (Rigolet et al. 2014a).

\section{Sampling strategy}

We used seafloor maps combining geophysical swath and sub-bottom profile imagery data collected during campaigns in 2005 and 2009 that were designed to define the contours of the pockmark field and the Haploops habitat (see details in Baltzer et al. 2014) (Fig. 1D). Importantly, pockmarks were exclusively found in the muddy habitat colonized by Haploops. Using the finest resolution available on bathymetrical maps ( $0.1 \mathrm{~m}$ latitude and longitude and $0.1 \mathrm{~m}$ depth), we selected 4 zones, corresponding roughly to areas of $2 \mathrm{~km}^{2}$ each, distributed along the Haploops habitat (Fig. 1D). In each zone, 3 pockmarks were randomly selected, providing they were isolated (i.e. not fused with one another or tightly clustered with many other pockmarks). The central position of each pockmark was located, and coordinates were recorded. A position outside any pockmark was located as the reference (control) for each zone. These control stations were selected to be in similar hydrosedimentary settings as the pockmarks but at least $100 \mathrm{~m}$ away from the edge of any pockmark. Besides locations and affiliation to a zone, each pockmark was examined using multibeam acoustic data and characterized in terms of water depth, depression depth and surface area (calculated considering pockmarks as ellipsoids) (Table 1). The spatial distribution of pockmarks was representative of conditions throughout the entire Haploops habitat.

Because water depth is $40 \mathrm{~m}$ or less, macrofauna and sediment sampling were performed by scuba divers. To avoid confusion where visibility was low, each pockmark was first marked by a buoy moored next to it. At the center of each pockmark, three $400 \mathrm{~cm}^{2}(20 \times 20 \mathrm{~cm}$, depth $15 \mathrm{~cm})$ cores were collected along with two $35 \mathrm{~cm}$ long cores of $10 \mathrm{~cm}$ diameter for sediment and porewater analysis. Once samples had been brought onboard, macrofauna sam- ples were sieved on a screen with a $1 \mathrm{~mm}$ circular mesh and fixed in a $5 \%$ buffered formalin solution. In the first sediment core, porewater was drawn off and filtered through porous polymer filters attached to syringes (Rhizon system, Shotbolt 2010) inserted every $2 \mathrm{~cm}$ (including at the water-sediment interface as 'zero') up to $8 \mathrm{~cm}$ and every $4 \mathrm{~cm}$ from $10 \mathrm{~cm}$ downward. Immediately after porewater extraction, $\mathrm{HgCl}_{2}$ was added to $2 \times 2 \mathrm{ml}$ aliquots for methane measurements, and $\mathrm{ZnCl}_{2}$ was added to $2 \times 2 \mathrm{ml}$ aliquots for sulfide $\left(\mathrm{H}_{2} \mathrm{~S}\right)$ analysis. One aliquot was saved as a backup. The analytical error was $4 \%$ for methane and $5 \%$ for $\mathrm{H}_{2} \mathrm{~S}$ measurements. The second sediment core was processed for sediment analyses; sediment was sampled between $0-2$ and $10-12 \mathrm{~cm}$ depth. For each depth, 1 subsample was kept at $4^{\circ} \mathrm{C}$ for granulometry, and another was kept at $-20^{\circ} \mathrm{C}$ for chl $a$ and organic matter analyses.

\section{Laboratory analyses}

Macrofauna samples were rinsed and sorted, and the macrofauna were identified to the lowest taxonomic level (i.e. generally species level) and counted. Identifications were performed using the latest issues of taxonomic guides and articles. Accurate scientific names were double-checked using the World Register of Marine Species database (www.marinespecies. org, accessed on May 4, 2014).

Methane concentrations were measured using static headspace gas chromatography (Sarradin \& 
Caprais 1996). Porewater sulfide concentrations were analyzed using standard photometric procedures (Cline 1969, Fonselius 1983). Values are expressed in micromoles per liter porewater.

Grain size distribution was analyzed using a laser particle analyzer, and granulometric parameters (i.e. mean grain size, sorting index and mud percentage) were estimated using GRADISTAT software (Blott \& Pye 2001). Percentages of nitrogen and carbon organic content in sediment were measured with an elemental analyzer after acidification with $1 \mathrm{M} \mathrm{HCl}$. The total organic matter in the sediment was also measured by loss on ignition (Dean 1974). Primary producer pigments (i.e. chl $a$ and phaeopigments) were estimated using the monochromatic technique (Lorenzen 1967) following Aminot \& Kérouel (2004).

\section{Statistical analysis}

Macrofauna diversity was assessed using indices recommended by Gray (2000) for characterizing local diversity, namely Hill's indices $\left(\mathrm{N}_{0}, \mathrm{~N}_{1}\right.$ and $\mathrm{N}_{2}$ ) (Hill 1973). As described in Hill (1973), $N_{0}$ corresponds to the species richness (number of species); $\mathrm{N}_{1}=\exp$ $\left(\mathrm{H}^{\prime}\right)$, where $\mathrm{H}^{\prime}$ is the Shannon-Wiener diversity $\left(\log _{\mathrm{e}}\right)$; and $\mathrm{N}_{2}=1 / \mathrm{SI}$, where SI is the Simpson's dominance index. The $\mathrm{N}_{1}$ and $\mathrm{N}_{2}$ indices are 2 measures of heterogeneity diversity (Gray 2000). The $\mathrm{N}_{1}$ index is mainly affected by species situated in the middle of the rank sequence, while the Simpson's index used in the calculation of $\mathrm{N}_{2}$ addresses the degree of dominance of 1 or a few very abundant species (Whittaker 1972). Diversity indices were calculated with and without the engineer species Haploops nirae, as the latter made it possible to focus on the associated fauna alone. Linear relationships were tested between diversity indices and environmental parameters using Pearson correlations on standardized values. A 1-way non-parametric ANOVA (KruskalWallis test) was used to test for significant differences between diversity indices and macrofauna abundances inside and outside pockmarks, between zones (1 to 4 ) or between statistical groups from hierarchical clustering. When a significant effect was reported, the Holm-Sidak multiple comparison test was performed. Analyses were performed using Sigmastat 3.5 software (Systat Software).

Multivariate statistics were performed using the software package PRIMER v. 6 (Clarke \& Gorley 2006). Species abundance values were log transformed before calculating a similarity matrix based on the Bray-Curtis similarity index. The differences in species composition between samples from outside (control) and inside pockmarks were first assessed using non-metric multidimensional scaling ordination (nMDS). A cluster analysis was combined with the nMDS to check for the validity of potential groupings. Species that appeared only once or twice in the dataset (i.e. occurring in less than $2 \%$ of the samples) were removed from the multivariate analyses. A similarity profile test was performed, using the SIMPROF routine, to test the null hypothesis that samples that are not a priori divided into groups do not differ from each other in the multivariate structure (Clarke \& Gorley 2006). Taxa that were predominantly responsible for the similarity within assemblages were determined from the Bray-Curtis similarity matrix using the SIMPER procedure (Clarke \& Gorley 2006).

To determine the relationships between species assemblages and environmental variables, a distancebased redundancy analysis (dbRDA) was performed (Anderson et al. 2008). The dbRDA is a method of constrained ordination that displays the relationships among sample points from a fitted model (Legendre \& Anderson 1999). The distance-based linear modeling (DISTLM) routine of the PERMANOVA+ add-on package for PRIMER was therefore used first to analyze and model the linear relationships between multivariate data (community composition) and predictor variables (environmental variables) (Anderson et al. 2008). The parsimonious model built by the DISTLM routine limits the number of environmental variables to those that best correlate with species assemblages. The criterion used to determine this model was the Akaike's information criterion. The dbRDA routine was then used to perform an ordination of fitted values from the given model built by the DISTLM routine. Preliminary diagnostics were made to avoid multicollinearity (strong intercorrelations) among predictor (environmental) variables. Thus, when 2 environmental variables showed strong correlation (i.e. $r>0.80$ ), 1 of these 2 variables was removed from the analysis, as recommended by Dormann et al. (2013), since they contain redundant information. Moreover, none of the environmental variables, except Haploops density, showed a great deal of skewness (identified by the use of Draftsman plots) and required log transformation to approach normality. Haploops density (log transformed) was regarded as an environmental variable included in the dbRDA analysis in a previous study, as Haploops tubes physically modify their habitat and can therefore be considered as an environmental variable (Rigolet et al. 2014a). To test whether Haploops tubes 

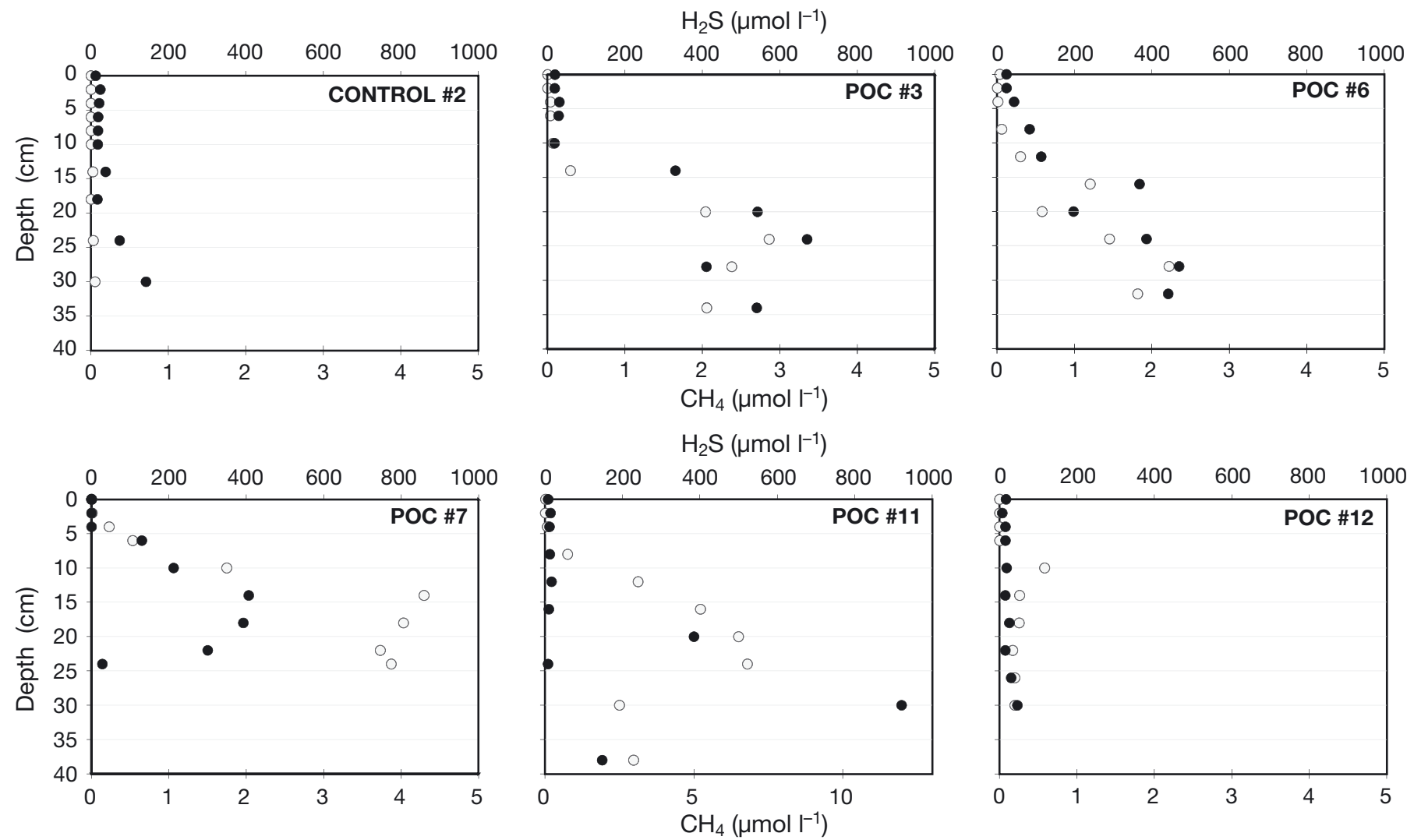

Fig. 2. Sediment profiles of total sulfides (O) and methane $\left(\mathrm{CH}_{4}, \bullet\right)\left(\mu \mathrm{mol} \mathrm{l}^{-1}\right)$ for some control (CONTROL \#2) and pockmark (POC \#3, POC \#6, POC \#7, POC \#11 and POC \#12) samples. The selected profiles are representative of the existing variability in $\mathrm{CH}_{4}$ and hydrogen sulfide $\left(\mathrm{H}_{2} \mathrm{~S}\right)$ patterns. Note that the $\mathrm{CH}_{4}$ axis of the POC \#11 sample differs from the others

actually affected species assemblages, the dbRDA analysis was run with Haploops either considered as an environmental parameter (and in that case, Haploops was removed from the species list) or removed from the set of environmental variables.

\section{RESULTS}

Environmental parameters revealed a positive north-south correlation between the water depth and the depression depth of the pockmarks $(r=0.72 ; p=$ 0.007 ) or the size (surface area) of the pockmarks ( $r=$ $0.65 ; \mathrm{p}=0.02$ ): the deeper the water column, the larger and deeper the pockmarks. Chl a concentrations in the sediments were highly correlated with phaeopigment concentrations $\left(\mathrm{r}=0.85 ; \mathrm{p}<10^{-4}\right)$ and organic matter concentrations $\left(\mathrm{r}=0.81 ; \mathrm{p}<10^{-4}\right)$ in the top sediment layers ( 0 to $8 \mathrm{~cm}$ ). Sediment characteristics also showed high positive correlations, as the mud percentage in the pockmarks was highly correlated with the mean grain size $\left(\mathrm{r}=-0.97 ; \mathrm{p}<10^{-4}\right)$ and the sorting index $\left(\mathrm{r}=-0.88 ; \mathrm{p}<10^{-4}\right)$. The surface area of the pockmark was not correlated with sediment characteristics, but the depression depth was negatively correlated with the mud content in surface $(\mathrm{r}=-0.51 ; \mathrm{p}=0.04)$ and subsurface sediments $(\mathrm{r}=-0.60 ; \mathrm{p}=0.01)$. As for porewater parameters, no correlation was found between pockmark morphological characteristics and $\mathrm{H}_{2} \mathrm{~S}$ or methane, with the exception of the methane concentration in the surface sediment $(0$ to $8 \mathrm{~cm}$ ) being negatively correlated with pockmark size $\left(\mathrm{r}=-0.83 ; \mathrm{p}<10^{-4}\right)$. Detailed analyses of porewater revealed a wide variety of depth profile variations in $\mathrm{H}_{2} \mathrm{~S}$ and methane concentrations (Fig. 2). Control samples showed very little change with depth (e.g. control \#2). Similarly, some pockmarks showed almost no change with depth (e.g. pockmark \#12). Most of the profiles showed sharp changes in $\mathrm{H}_{2} \mathrm{~S}$ and methane concentrations between 5 and $10 \mathrm{~cm}$ depth, with either a regular increase (e.g. pockmark \#6) or a rapid increase (e.g. pockmark \#3). $\mathrm{H}_{2} \mathrm{~S}$ and methane concentrations followed the same variation pattern, except in some 
pockmarks (e.g. pockmark \#7) where the methane concentrations decreased while $\mathrm{H}_{2} \mathrm{~S}$ concentration remained high. The maximum $\mathrm{H}_{2} \mathrm{~S}$ and methane concentrations were 975.66 and $11.97 \mu \mathrm{mol} \mathrm{l}^{-1}$, respectively.

A total of 166 species were found in the macrofauna samples. All nemertean species (5 potential species) were pooled because of uncertainties in identifying them to species level. The overall mean sample species richness was 42.75 species $(\mathrm{SE}=$ 0.77 ). There were no significant differences in diversity indices between sampling zones. Diversity measures and environmental parameters in pockmark samples revealed significant negative linear relationships between $\mathrm{N}_{0}, \mathrm{~N}_{1}$ and $\mathrm{N}_{2}$ and the $\mathrm{H}_{2} \mathrm{~S}$ concentration in subsurface sediments below $10 \mathrm{~cm}$ as well as significant negative relationships between $\mathrm{N}_{1}$ and $\mathrm{N}_{2}$ with the $\mathrm{H}_{2} \mathrm{~S}$ concentration in the sediment above $10 \mathrm{~cm}$ ( $\mathrm{r}$ values between 0.58 and $0.74>0.57$; $\mathrm{p}<$ 0.05 ). Additionally, all diversity indices were significantly correlated with Haploops density (log transformed).
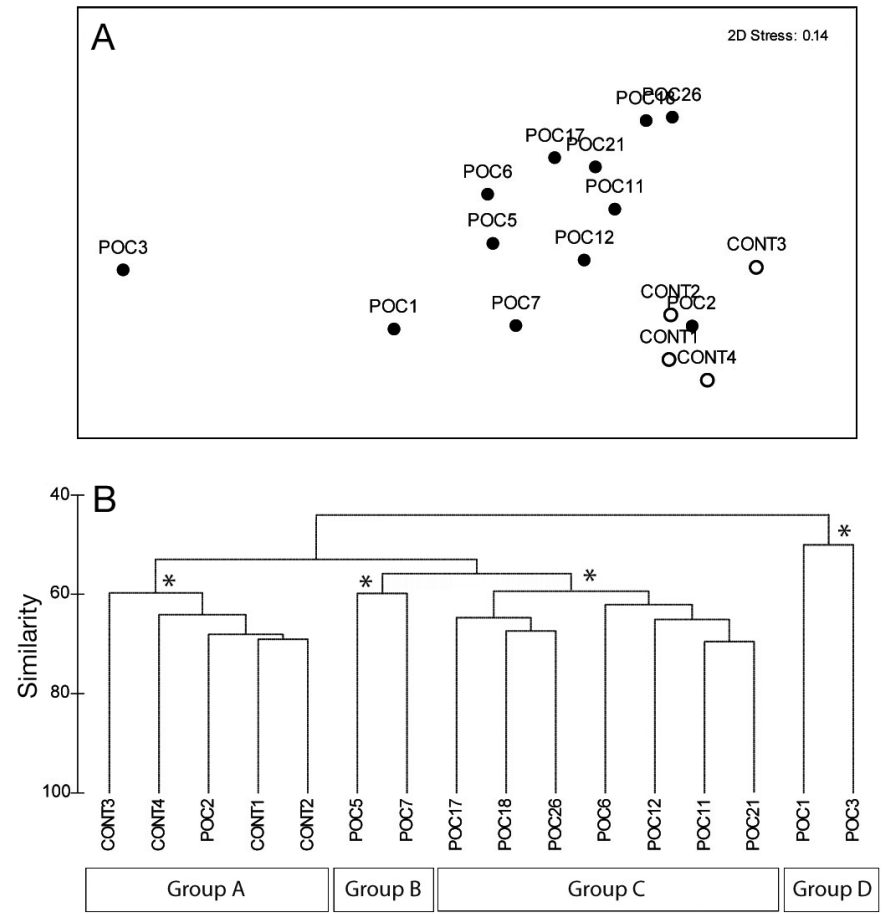

Fig. 3. (A) Non-metric multidimensional scaling ordination of species abundances, excluding species occurring in less than $5 \%$ of the samples. POC refers to samples inside pockmarks $(\bullet)$, and CONT refers to control or outside samples (O). (B) Cluster ordination (group average dendrogram) of samples for inside (POC samples) and outside (CONT samples) pockmarks. Asterisks (*) indicate significant groupings (groups $\mathrm{A}$ to $\mathrm{D}$ ) according to the SIMPROF procedure $(\mathrm{p}$-level $=0.05)$
The nMDS ordination of species assemblage abundances (log transformed) showed a sharp segregation between control stations and pockmark stations, with the exception of samples extracted from pockmark \#2, which clustered with the control stations (Fig. 3A). The dendrogram from the similarity matrix showed 4 significantly different statistical groups of samples, as validated by the SIMPROF test (at a $5 \%$ significance level) (Fig. 3B). Species typifying each group are listed in Table 2. Group A contains all control samples from outside pockmarks and those from within pockmark \#2. Haploops nirae contributed the most to the similarity, along with the 3 deposit-feeding polychaetes Terebellides stroemii, Mediomastus fragilis and Paradoneis lyra. The samples from group B (pockmarks \#5 and \#7) were characterized by high occurrence and high density of the hermit crab Anapagurus hyndmanni. Group C included the largest number of samples (pockmarks \#6, \#11, \#12, \#17,

Table 2. Species typifying each group of samples (see clustering ordination in Fig. 3). Taxonomic groups and main feeding behaviour are reported in parentheses: $\mathrm{N}=$ nemertean; $\mathrm{P}=$ polychaete; $\mathrm{C}=$ crustacean; $\mathrm{M}=$ mollusc $; \mathrm{S}=$ sipunculid $; \mathrm{E}=$ echinoderm; $\mathrm{SF}=$ suspension feeder; DF = surface or subsurface deposit feeder; PS $=$ predator and/or scavenger. Overall percentages of similarity are indicated for each group as well as the cumulative contribution of each species to similarity within each group

\begin{tabular}{|c|c|c|c|}
\hline Group & $\begin{array}{l}\text { Simi- } \\
\text { larity } \\
(\%)\end{array}$ & Species name & $\begin{array}{l}\text { Cumulative } \\
\text { ontribution to } \\
\text { imilarity ( } \%)\end{array}$ \\
\hline A & 63.6 & $\begin{array}{l}\text { Haploops nirae }(\mathrm{C}, \mathrm{SF}) \\
\text { Terebellides stroemii }(\mathrm{P}, \mathrm{DF}) \\
\text { Mediomastus fragilis }(\mathrm{P}, \mathrm{DF}) \\
\text { Paradoneis lyra }(\mathrm{P}, \mathrm{DF}) \\
\text { Schistomeringos rudolphi }(\mathrm{P}, \mathrm{PS}) \\
\text { Aphelochaeta marioni }(\mathrm{P}, \mathrm{DF})\end{array}$ & $\begin{array}{r}9.51 \\
15.00 \\
20.06 \\
24.67 \\
29.18 \\
33.03\end{array}$ \\
\hline B & 59.8 & $\begin{array}{l}\text { Anapagurus hyndmanni (C, PS) } \\
\text { Schistomeringos rudolphi (P, PS) } \\
\text { Paradoneis lyra (P, DF) } \\
\text { Aspidosiphon muelleri (S, DF) } \\
\text { Nermertea spp. (N, PS) }\end{array}$ & $\begin{array}{l}10.17 \\
16.76 \\
23.18 \\
29.40 \\
35.27\end{array}$ \\
\hline $\mathrm{C}$ & 61.7 & $\begin{array}{l}\text { Paradoneis lyra (P, DF) } \\
\text { Hilbigneris gracilis (P, PS) } \\
\text { Amphipholis squamata (E, PS) } \\
\text { Nermertea spp. (N, PS) } \\
\text { Heteromastus filiformis (P, DF) } \\
\text { Aphelochaeta marioni (P, DF) } \\
\text { Pholoe inornata (P, PS) } \\
\text { Euclymene santandarensis (P, DF) }\end{array}$ & $\begin{array}{r}6.08 \\
10.74 \\
14.67 \\
18.60 \\
22.49 \\
26.12 \\
29.57 \\
\text { F) } 32.89\end{array}$ \\
\hline $\mathrm{D}$ & 50.1 & $\begin{array}{l}\text { Hilbigneris gracilis (P, PS) } \\
\text { Nermertea spp. (N, PS) } \\
\text { Abra alba }(\mathrm{M}, \mathrm{DF}) \\
\text { Aphelochaeta marioni (P, DF) }\end{array}$ & $\begin{array}{r}8.81 \\
17.62 \\
25.26 \\
32.38\end{array}$ \\
\hline
\end{tabular}


Table 3. Comparisons of diversity indices $\left(\mathrm{N}_{0}, \mathrm{~N}_{1}\right.$ and $\left.\mathrm{N}_{2}\right)$ and overall mean density of macrofauna samples for each statistical sample group. Calculations were performed with the whole species list, including Haploops nirae. Superscript letters refer to the post hoc tests (Holm-Sidak method) when differences in the mean values of the dependent variable are significantly different (non-parametric ANOVA, KruskalWallis test, $\mathrm{p}<0.05$ )

\begin{tabular}{|lllcc|}
\hline Group & $\begin{array}{c}\text { Species } \\
\text { richness } \\
\left(\mathrm{N}_{0}\right)\end{array}$ & $\mathrm{N}_{1}$ index & $\mathrm{N}_{2}$ index & $\begin{array}{c}\text { Mean } \\
\text { density } \\
\left.\text { (ind. } \mathrm{m}^{-2}\right)\end{array}$ \\
\hline $\mathrm{A}$ & $48.4 \pm 5.6$ & $11.6 \pm 1.1^{\mathrm{a}}$ & $4.2 \pm 0.5^{\mathrm{a}}$ & $3728 \pm 853$ \\
$\mathrm{~B}$ & $46.0 \pm 2.8$ & $19.0 \pm 0.4^{\mathrm{ab}}$ & $10.0 \pm 0.5^{\mathrm{b}}$ & $2503 \pm 1197$ \\
$\mathrm{C}$ & $53.9 \pm 2.4$ & $24.9 \pm 1.9^{\mathrm{ab}}$ & $13.5 \pm 1.4^{\mathrm{b}}$ & $2619 \pm 351$ \\
$\mathrm{D}$ & $32.1 \pm 9.9$ & $18.8 \pm 1.1^{\mathrm{b}}$ & $12.7 \pm 0.9^{\mathrm{b}}$ & $935 \pm 1786$ \\
\hline
\end{tabular}

\#21, \#18 and \#26). The species that most typified this group were the polychaetes P. lyra and Hilbigneris gracilis and the ophiuroid Amphipholis squamata. All samples also had a high density of nemerteans. Group D comprised samples from pockmarks \#1 and \#3 and was typified by $H$. gracilis and a high occurrence of nemerteans with densities half those of group C. The bivalve Abra alba also typified group D samples. Differences in species richness $\left(\mathrm{N}_{0}\right)$ or species density were not statistically significant between these groups, but $\mathrm{N}_{1}$ and $\mathrm{N}_{2}$ indices were significantly higher in group A samples (i.e. control samples + pockmark \#2) compared with pockmark samples (Table 3).

Environmental data synthesized for each statistical group are presented in Table 4. Differences among sample groups were tested with Kruskal-Wallis tests, revealing variations between group A control samples and the other groups. More precisely, group A samples had the highest Haploops density combined with the lowest $\mathrm{H}_{2} \mathrm{~S}$ and methane concentrations for subsurface samples and levels close to zero for the surface samples. Groups B and D showed the highest $\mathrm{H}_{2} \mathrm{~S}$ and methane concentrations in surface and subsurface samples, even though methane concentrations did not show statistically significant variations. Group B samples generally had the lowest mud content with the largest mean grain size and the poorest sorting index. They also showed the lowest Haploops density and the lowest phaeopigment and chl a concentrations (Table 4).

Multivariate analyses revealed that samples from inside and outside pockmarks were clearly separated on the dbRDA axes (Fig. 4). The environmental parameters represented on the first 2 axes accounted for $40.5 \%$ of the total variation. To avoid multicollinear-

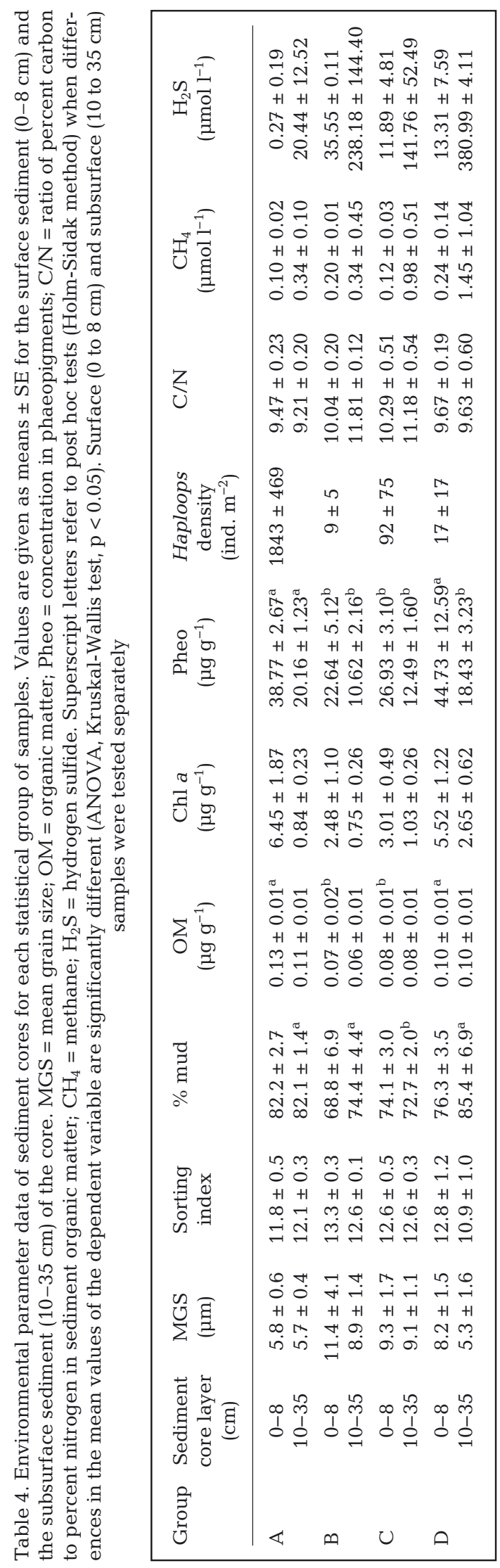




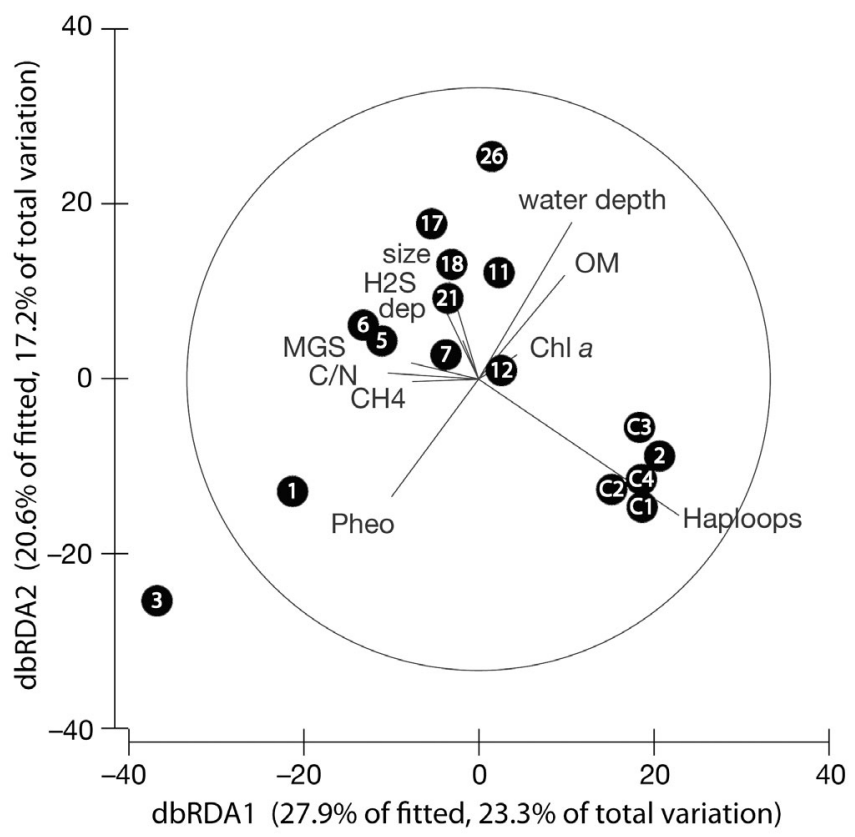

Fig. 4. Distance-based redundancy analysis (dbRDA) showing the relationships between species assemblages and environmental variables inside and outside pockmarks, based on the distance-based linear modeling routine. Numbers refer to pockmark number or control (C) stations. All variables were included in the model that best correlated with species assemblages: $40.5 \%$ of the variation was explained. $\mathrm{CH} 4=$ methane; $\mathrm{C} / \mathrm{N}=$ carbon to nitrogen ratio; dep = depression depth; H2S = hydrogen sulfide; $\mathrm{MGS}=$ mean grain size; $\mathrm{OM}=$ organic matter; Pheo = concentration in phaeopigments

ity among predictor variables, we only selected parameters from the surface sediment and porewater ( 0 to $8 \mathrm{~cm}$ ). The sorting index and mud percentage (highly correlated with mean grain size) were removed. The DISTLM routine indicated that the most parsimonious model, which best correlated environmental variables with species assemblages, comprised all selected environmental variables. The occurrence of the engineer tubiculous species Haploops as a variable partly explained the grouping between pockmark \#2 and control samples (group A), but the same results appeared if Haploops density was excluded as a variable, as all of these samples were also characterized by very low $\mathrm{H}_{2} \mathrm{~S}$ and methane concentrations. Samples from pockmarks \#1 and \#3 (group D) were extracted from small pockmarks, with high phaeopigment concentrations and the highest methane concentrations (Tables $1 \& 4$ ). Samples from pockmarks \#5 and \#7 (group B) were extracted from rather large pockmarks, with high highest $\mathrm{H}_{2} \mathrm{~S}$ concentrations on the whole sediment core. Samples from group $\mathrm{C}$ were extracted from pockmarks of various sizes and depression depths with rather low $\mathrm{H}_{2} \mathrm{~S}$ and methane concentrations and intermediate Haploops density.

\section{DISCUSSION}

Pockmarks are one of the major seabed features known to create heterogeneity in benthic habitats (Wildish et al. 2008, Webb et al. 2009a). They create potential refuges for prey species and may allow many sessile organisms to escape from disturbances such as trawling. However, the role of pockmarks in structuring benthic diversity is not yet understood. Most studies carried out on pockmark ecology have dealt with only 1 or 2 giant pockmarks (e.g. Dando et al. 1991 in the North Sea, Olu-Leroy et al. 2007 off the coast of West Africa, Sorbe et al. 2010 in the Bay of Biscay or Decker et al. 2012 on the Norwegian margin). To our knowledge, only Wildish et al. (2008) and Webb et al. $(2009 a, b)$ investigated macrobenthic and megabenthic diversity associated with coastal pockmark fields, which they did in Passamaquoddy Bay (Canada) and in the Oslofjord (Norway), respectively. Using video techniques, both studies revealed obvious differences between megafauna assemblages found inside and outside pockmarks, but changes in macroinfauna composition (assessed using grab samples) were concealed by large environmental gradients or were unclear and non-significant (Webb et al. 2009b). In the present study, we investigated a small single habitat of around $10 \mathrm{~km}^{2}$ so that large coastal environmental gradients were minimized. Baltzer et al. (2014) showed that the pockmark field in South Brittany resulted from Holocene deposits covered by an Oligocene palaeovalley system. Geophysical exploration of pockmark fields using complementary approaches (chirp profiles, seabed sonar imagery and ultrasonic backscatter data) revealed similar topographic and stratigraphic control of pockmark distribution in other coastal areas, such as Passamaquoddy Bay (Brothers et al. 2011) or the Norwegian fjords (Webb et al. 2009c).

Baltzer et al. (2014) also showed that no pockmarks were found outside the Haploops nirae habitat in the Bay of Concarneau. In pockmarks where Haploops density is low, Haploops tube debris was found in sediment cores down to $1 \mathrm{~m}$ depth. Generations of Haploops population lead to silt and sandy silt layers (with abundant tube debris), where gas can easily accumulate and concentrate in subsurface sediment layers (i.e. 20 to $30 \mathrm{~cm}$ ). Ultimately, pockmarks are formed through triggering mechanisms such as tidal 
pressure. As revealed with the seismic profiles, muddy sediments outside the Haploops habitat are less gassy in their subsurface layers but show deeper gas horizons (Baltzer et al. 2014). Dense Haploops tube mats were also reported in the Bay of Fundy ( $H$. fundiensis, Wildish \& Dickinson 1982) or in the adjacent Cobscook Bay (Maine, USA) (H. spinosa, Larsen 2005) and in the Skagerrak ( $H$. tubicola and $H$. tenuis, Göransson 2002). Interestingly, all of these sedimentary environments have pockmark fields nearby (Passamaquoddy Bay, Canada, or Oslofjord, Norway). The tube-building activity of Haploops spp. populations, even past ones, could hence reveal gas accumulation in subsurface sediments that facilitates gas eruptions in coastal shallow waters. The obligate association between the Haploops spp. community and nearby pockmark occurrence makes this hypothesis a reasonable possibility.

Dando \& Southward (1996) or Wildish et al. (2008) both found a lower species richness and macrofauna density inside compared with outside pockmarks. Dando \& Southward (1996) suggested that fluid leakage was possibly affecting sedimentary composition and preventing species from settling. Wildish et al. (2008) interpreted the few depauperate pockmarks as an early stage of pockmark evolution. Unlike these previous studies, the present investigation showed neither species richness $\left(\mathrm{N}_{0}\right)(\mathrm{p}=0.448)$ nor species abundance $(\mathrm{p}=0.571)$ to be significantly different between the areas inside and outside of pockmarks. Also, heterogeneity diversity indices $\left(\mathrm{N}_{1}\right.$ and $\left.\mathrm{N}_{2}\right)$ were both significantly higher inside the pockmarks, indicating that species colonizing pockmarks are more evenly distributed. This likely indicates that the studied pockmarks in South Brittany are no longer leaking fluid (methane). Sonar imagery of the whole area (see example in Fig. 1) revealed very few 'eyed pockmarks' sensu Hovland et al. (2002) where secondary fluid leaking could be observed.

Unlike Webb et al. (2009b), we showed that macrofauna assemblages are very different inside and outside pockmarks. Rigolet et al. (2012, 2014a) showed that $H$. nirae is an engineer species that affects and controls associated species by strongly modifying hydrosedimentary features at the water-sediment interface. The infauna found outside pockmarks is typical of the Haploops community and was dominated by the deposit-feeding polychaetes Terebellides stroemii, Mediomastus fragilis and Paradoneis lyra, along with the predatory polychaete Shistomeringos rudolphi. Samples from pockmark \#2 revealed a high density of $H$. nirae (3155 ind. $\mathrm{m}^{-2}$, SE $=18$ ), together with the same associated fauna. The obvious differences between composition inside and outside pockmarks were still evident, with $H$. nirae excluded from the species matrix, hence indicating the strong homogeneity of species assemblages within the Haploops habitat. Environmental parameters from control and group A pockmarks showed the lowest methane and $\mathrm{H}_{2} \mathrm{~S}$ concentrations from porewater analyses but the highest organic matter and $\mathrm{chl}$ a concentrations as well as the highest mud percentage in the sediment. At high density, tubiculous species tend to disturb hydrodynamic patterns at the sediment-water interface and increase fine sedimentation among tubes (e.g. Callaway et al. 2010), but Haploops tubes have also been shown to sustain the growth of benthic diatoms, which explains the high chl a values (Rigolet et al. 2014b). In addition, deflection of currents by a pockmark and the enhanced turbulence could contribute to reduced sedimentation rate and/or increased resuspension of fine particles from the seabed in pockmarks. By investigating currents and sedimentation rates inside and around 2 inactive pockmarks in the Oslofjord, Pau \& Hammer (2013) showed that sedimentation and resuspension rates could be higher inside pockmarks than outside, removing much of the fine-grained material and very likely the organic matter. This hypothesis is thus consistent with the presence of coarser sediments reported in most pockmarks in the Bay of Concarneau in comparison with the Haploops habitat.

Between all pockmark samples, the variations in species assemblages were much higher than the variations between control samples, likely indicating a wide range in pockmark evolution or aging. It seems intuitively reasonable that newly created pockmarks will have higher depression depths with few or no Haploops individuals. With time, sedimentation will fill craters, so that the depression depth will tend toward zero with an increasing colonization of Haploops. From this point of view, each pockmark is at a different stage in its evolution. Similar to Webb et al. (2009c), Pau \& Hammer (2013) interpreted the relatively deeper pockmarks to be newly formed and the shallower ones to have experienced sediment filling. However, the behaviour of some pockmarks did not seem to follow this pattern, as they had lower sedimentation rates than the outside areas. Local variations in hydrodynamic conditions (Hammer et al. 2009) and/or biological activity of fish (Hovland \& Judd 1988) can explain large differences in pockmark behavior. Numerical modeling revealed that upwelling currents can be possible mechanisms that maintain pockmark structures even if activity has ceased (Pau \& Hammer 2013). Large variability in the 
characteristics of pockmark groups, including evolution and/or age of each pockmark, is likely to explain why previous investigations showed contradictory results when comparing macrofauna species diversity and composition inside and outside pockmarks (Wildish et al. 2008, Webb et al. 2009b). While it would require more investigation to determine each pockmark's age, this factor appeared to be of primary importance in understanding changes in associated macrofauna assemblages, as suggested by Wildish et al. (2008) for Passamaquoddy Bay pockmarks.

The fauna inside pockmarks was characterized overall by predators/scavengers such as the crustaceans Anapagurus hyndmanni and Pagurus bernhardus or the polychaete Glycera alba. However, species composition analyses showed 3 groups of pockmarks that illustrate the continuum of changes from creation to levelling with surrounding habitat (shown here by pockmark \#2). A first group of pockmarks (group B) had the highest depression depths and was characterized by the highest methane and $\mathrm{H}_{2} \mathrm{~S}$ concentrations in porewater of the first centimeters of the sediment core $(0.20 \pm 0.01$ and $35.55 \pm$ $0.11 \mu \mathrm{mol} \mathrm{l}^{-1}$, respectively). They had almost no living Haploops, although divers reported disarray on the bottom, with a massive amount of Haploops tubes and shell fragments lying around. These pockmarks had the largest mean grain size and the lowest mud percentage of those examined. SIMPER analysis showed that in addition to A. hyndmanni, predators such as $S$. rudolphi and nemerteans typified the infauna, along with sipunculids (Aspidosiphon muelleri) living in empty shells. Altogether, the data suggest that these pockmarks were created recently, which is supported by the high depression depth and methane and $\mathrm{H}_{2} \mathrm{~S}$ concentrations but also because they have the lowest Haploops density and the highest predator/scavenger density. Bagarinao (1992) and Sims \& Moore (1995) made a review of the literature that focused on the adverse effects of $\mathrm{H}_{2} \mathrm{~S}$ on benthic organisms. They reported that tube-building amphipods (a group that includes Haploops) circulate oxygenated water through their tubes, thus reducing exposure to porewater $\mathrm{H}_{2} \mathrm{~S}$. It is hypothesized here that Haploops juveniles seek sediments with the lowest $\mathrm{H}_{2} \mathrm{~S}$ concentrations, hence avoiding recent pockmarks (i.e. group B) and preferentially building their own tubes among other tubes. A second group of pockmarks (group D) still had relatively high methane and $\mathrm{H}_{2} \mathrm{~S}$ concentrations in surface sediments in comparison with the group B pockmarks $(0.24 \pm 0.14$ and $13.31 \pm 7.59 \mu \mathrm{mol} \mathrm{l}^{-1}$, respectively) but a smaller depression depth, a smaller mean grain size and a higher mud percentage. A third group of pockmarks (group C) showed large variations in environmental parameters but, unlike other pockmarks, had very low $\mathrm{H}_{2} \mathrm{~S}$ concentrations in porewater below $10 \mathrm{~cm}$ depth $\left(141.76 \pm 52.49 \mu \mathrm{mol} \mathrm{l} \mathrm{l}^{-1}\right.$ in comparison to $238.18 \pm 140.4$ and $380.99 \pm 4.11 \mu \mathrm{mol} \mathrm{l}^{-1}$ in groups B and $\mathrm{D}$, respectively). They also showed intermediate and highly variable Haploops density $(92 \pm 75$ ind. $\mathrm{m}^{-2}$ ). The fauna associated with groups $C$ and D was typified by similar species, such as the predators Hilbigneris gracilis and Nemertea or the depositfeeder Aphelochaeta marioni, but Abra alba was found in high density in group $\mathrm{D}$ pockmarks. In group C, more species would be needed to reach the $30 \%$ similarity threshold (Table 2 ) and the mean species richness (as given by the positive correlation between $\mathrm{N}_{0}$ and Haploops density). The variations in sediment characteristics and biology between group $\mathrm{C}$ and D pockmarks suggest that group $\mathrm{C}$ pockmarks are potentially more mature than group D pockmarks. Interestingly, many species found in the pockmarks were not found, or occurred only rarely, in control samples from the Haploops habitat (present study) and more generally in numerous samples collected outside pockmarks in the Haploops habitat (Rigolet et al. 2014a). They were not revealed by the SIMPER analysis either, because of a lower contribution to similarity (threshold cutoff $30 \%$ ) or because they appeared in fewer than 3 replicates (61 species out of 166 species total). Regardless of statistical grouping, the bivalves Corbula gibba and Kurtiella bidentata; crustaceans Orchomenella nana and Ampelisca typical; or polychaetes Prionospio cirrifera, Nephtys hystricis, Lagis koreni and Glycera lapidum were only found in pockmark samples and are known to be commonly found in sandy mud or muddy sand surrounding the Haploops habitat (Ehrhold et al. 2006, Rigolet et al. 2014b). Pockmarks are therefore acting as local spots where species which cannot normally develop among Haploops tube mats can settle. Pockmarks hence increase local alpha diversity (as shown by the higher $\mathrm{N}_{1}$ and $\mathrm{N}_{2}$ heterogeneity diversity indices in pockmark samples) but also beta diversity, defined as the variations in community structure among sample units within a given area (Anderson et al. 2011). Pockmarks appear to be a factor that increases heterogeneity within and between habitats. At the scale of a single pockmark, changes in diversity are temporary (a matter of a few seasons) and hence of temporal inconsequence. However, in the Bay of Concarneau, pockmarks are being formed continuously (Baltzer et al. 2014), and all different successional stages are represented. 
Because of the very high density of pockmarks in this region (up to 2500 pockmarks $\mathrm{km}^{-2}$ ), they should be considered as a key feature for understanding and explaining diversity patterns in macrofauna assemblages associated with benthic habitats. Although based on a limited number of pockmarks, we propose a schematic evolution of coastal pockmark ecology in Fig. 5, combining species and environmental data as well as professional divers' observations. Even though a chemosynthetic community has not been found here, the pockmark evolution progression shares some similarities to gas vent evolution theory in deeper ocean environments (e.g. Lapham et al. 2008). On a different temporal and spatial scale, Nickel et al. (2012) proposed a pockmark formation theory in pockmark fields of the southwestern Bar-
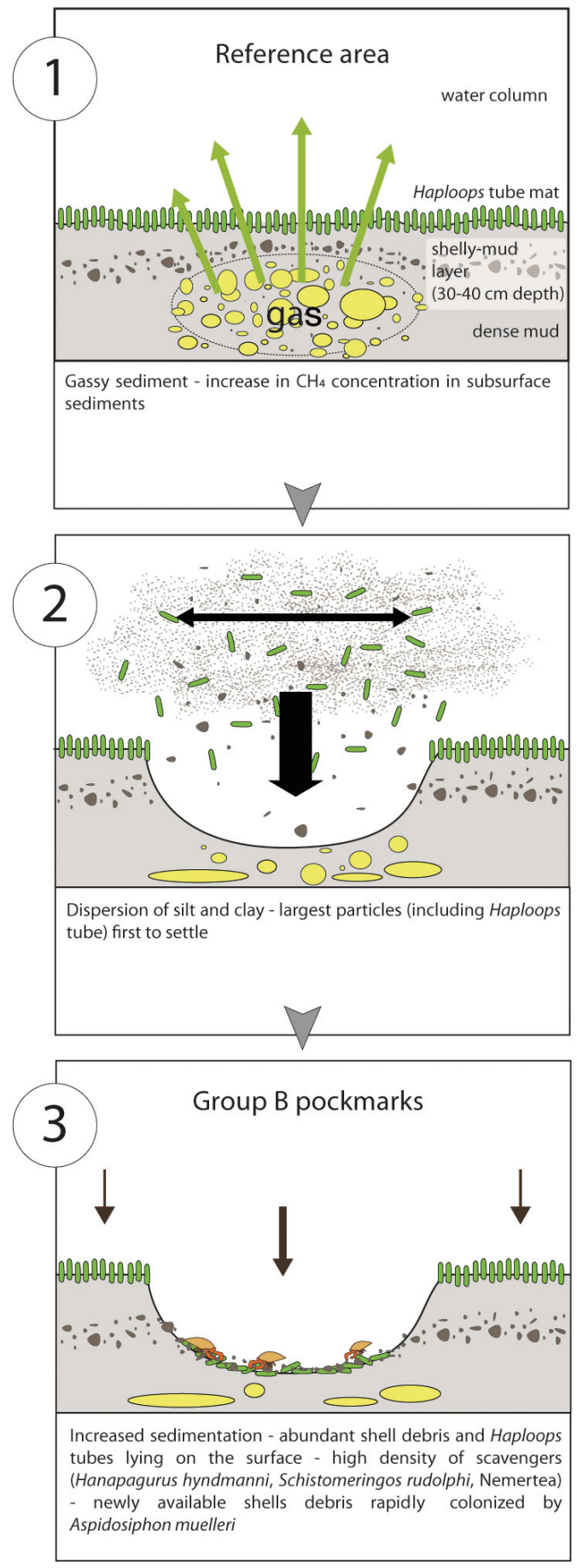
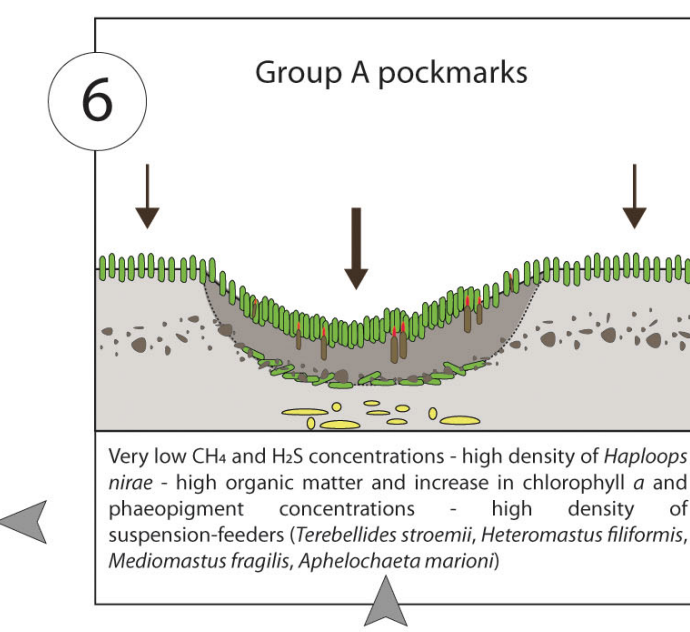

Very low $\mathrm{CH}_{4}$ and $\mathrm{H}_{2} \mathrm{~S}$ concentrations - high density of Haploops nirae - high organic matter and increase in chlorophyll $a$ and phaeopigment concentrations - high density of suspension-feeders (Terebellides stroemii, Heteromastus filiformis, Mediomastus fragilis, Aphelochaeta marioni)
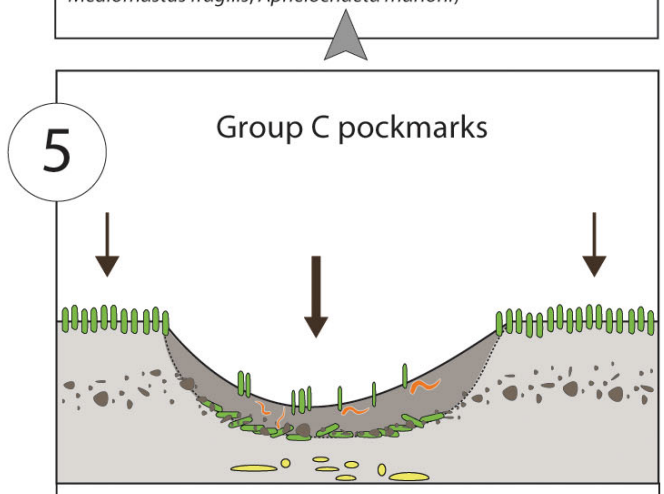

Sediment with low $\mathrm{CH}_{4}$ and $\mathrm{H}_{2} \mathrm{~S}$ concentrations - newly colonized by Haploops nirae - fauna assemblage typified by species living in enriched organic matter sediment (Heteromastus filiformis) - common pockmark infauna predators (Hilbigneris gracilis and Nemertea)

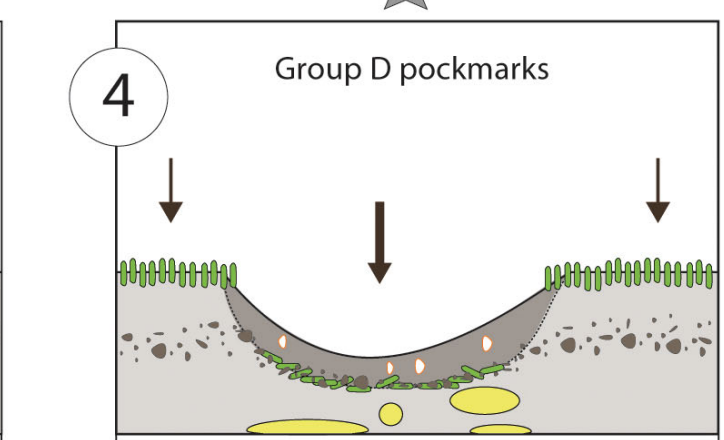

Sediment with high $\mathrm{CH}_{4}$ and $\mathrm{H}_{2} \mathrm{~S}$ concentrations - increased silting of pockmark - fauna characterized by deposit-feeders living on fluid mud and tolerating $\mathrm{H}_{2} \mathrm{~S}$ (Abra alba and Aphelochaeta marioni) - predators still numerous (Hilbigneris gracilis and Nemertea)
Fig. 5. Creation and evolution of pockmarks in South Brittany within the Haploops habitat. Steps 1 to 6 combine species collection and environmental data as well as divers' observations and records. Species mentioned in the captions are listed in Table 2. $\mathrm{CH}_{4}=$ methane; $\mathrm{H}_{2} \mathrm{~S}=$ hydrogen sulfide 
ents Sea, where dissolved sulfate and methane concentrations in porewater showed high similarities with the present investigation. They hypothesised that the retreat of the ice sheet during deglaciation (ca. 14000 yr ago) caused the necessary changes in pressure condition for the release of gas accumulated during the Last Glacial Maximum (ca. 20000 yr ago) and ultimately the formation of unit pockmarks, today inactive. According to Baltzer et al. (2014), the pockmark field in the Bay of Concarneau is still active and is triggered by tidal pressure and sporadic seismic activity. These authors demonstrated that the biogenic gas originates from Oligocene palaeovalleys, and we hypothesize that the formation of the Concarneau pockmark field is also correlated with the timing of the last deglaciation.

Although the triggering mechanisms that lead to pockmark creation remain to be investigated, one can safely assume that the necessary releases of gas or fluid are episodic and ephemeral in nature (Wildish et al. 2008). Preliminary analyses showed that the Haploops habitat is composed of gassy sediment with up to $400 \mu \mathrm{mol} \mathrm{l}^{-1}$ methane in the porewater, indicating ubiquitous gas accumulation in surface sediments (Baltzer et al. 2014). Methane concentration in the sampled pockmarks was actually very low, with a maximum of $12 \mu \mathrm{mol} \mathrm{l}^{-1}$, suggesting little or no fluid leakages after bubbling. Unlike previous findings for deep-sea pockmarks (Olu-Leroy et al. 2007, Decker et al. 2012), we did not find any evidence of macrofauna thriving on chemosynthetic microorganisms (e.g. vesicomyid bivalves or siboglinid tube worms) or bacterial mats (e.g. Beggiatoa sp.). Conversely, there is little evidence of macrofauna making direct use of this methane or sulfur energy source either. The bivalve Thyasira flexuosa, which contains endosymbiotic sulfur-oxidising bacteria (Brissac et al. 2011), was however only found in pockmark samples, with the highest density (43 ind. $\mathrm{m}^{-2}, \mathrm{SE}=31$ ) in pockmark \#11, where the highest methane concentration was found (Fig. 3). Thyasira sp. were noted as markers of giant active pockmarks in the North Sea, for example (Dando \& Southward 1986, Dando et al. 1991), and were reported as minor components of the fauna associated with Passamaquoddy Bay pockmarks (Wildish et al. 2008) and Oslofjord pockmarks (Webb et al. 2009b). Wildish et al. (2008) also reported large Beggiatoa sp. mats on the sidewalls of some pockmarks in Passamaquoddy Bay. No such bacterial mats have been reported in the South Brittany pockmark field so far. However, we emphasize here the differences in number and size of the pockmarks worked on by Dando \& Southward (1996) and
Wildish et al. (2008), which were less numerous and much smaller compared to the Bay of Concarneau pockmarks. To our knowledge, none of the previous investigations of coastal pockmark fields quantified methane or $\mathrm{H}_{2} \mathrm{~S}$ concentrations in pockmarks sampled for macrofauna (Wildish et al. 2008, Webb et al. 2009a). Wildish et al. (2008) determined sulfide concentration in only 2 pockmark cores. They measured concentrations from the same order of magnitude, spanning from 400 to $1600 \mu \mathrm{mol} \mathrm{l}^{-1}$, with a similar peak at around 15 to $20 \mathrm{~cm}$ depth. As in Wildish et al. (2008), we hypothesised here that after bubbling, the remaining residual methane from pockmark sediments is oxidised with seawater sulfate (i.e. $\mathrm{SO}_{4}{ }^{2-}+$ $\mathrm{CH}_{4} \rightarrow \mathrm{HS}^{-}+\mathrm{HCO}^{3-}+\mathrm{H}_{2} \mathrm{O}$ ) and accounts for the high sulfide concentrations found at increasing depth in our samples and the low methane concentrations following the $\mathrm{H}_{2} \mathrm{~S}$ variations. However, because our core samples only went to a maximum depth of $35 \mathrm{~cm}$, we were not able to locate the depth where seawater sulfates become limiting and prevent the anaerobic pathway described above (Borowski et al. 1996). Haploops are active tube builders, but they only rework the first few centimeters of the sediment. Individuals leave tubes every year (for example after completion of their life cycle, Rigolet et al. 2012). Because tubes are made with a mixture of solidified mucus and fine particles (Rigolet et al. 2011), tubes and tube fragments resist mechanical and microbial fragmentation. Sediment cores revealed tube fragments below $1 \mathrm{~m}$ (Baltzer et al. 2014), and we hypothesize that they affect sediment properties, including gas and water exchanges. Unlike bare muddy sediments, the accumulation of tubes renders the sediment porous, which likely explains why the peak in sulfates is deeper than in the pockmarks sampled by Wildish et al. (2008). In other words, Haploops activity has an effect on the sulfate-methane transition zone long after the population has gone. Only deeper sediment cores and associated sulfate measurements (of several meters) could ultimately provide further information on where the predicted sulfate concentrations approach the detection limit.

Acknowledgements. We thank the crew of the RV 'Thalia' and J. D. Gaffet for their support at sea as well as the whole scuba-diving team for a tremendous sampling effort (especially S. Robert, A. Curd, H. Goraguer, L. Dussud and L. Boucher). We also thank J. Bruchet and P. Pignet, who provided assistance in porewater analyses. We are grateful to C. Chevalier for help in species identification and to C. Cordier for collecting GIS information and designing Fig. 1. C.R. was supported by a regional PhD grant. S.F.D. was funded by the French national program EC2CO-BIO 
HEFECT/DRIL, DIVHA and the Total Foundation - Oceans and Biodiversity program. H. McCombie (Bureau de Traduction de l'Université de Bretagne Occidentale) revised and edited the manuscript.

\section{LITERATURE CITED}

Aminot A, Kérouel R (2004) Hydrologie des écosystèmes marins: paramètres et analyses. Editions de l'Ifremer, Plouzané

Anderson MJ, Gorley RN, Clarke KR (2008) PERMANOVA+ for PRIMER: guide to software and statistical methods. PRIMER-E, Plymouth

Anderson MJ, Crist TO, Chase JM, Vellend M, Inouye BD and others (2011) Navigating the multiple meaning of $\beta$ diversity: a roadmap for the practicing ecologist. Ecol Lett 14:19-28

Bagarinao T (1992) Sulfide as an environmental factor and toxicant: tolerance and adaptations in aquatic organisms. Aquat Toxicol 24:21-62

Baltzer A, Ehrhold A, Rigolet C, Souron A, Cordier C, Clouet H, Dubois SF (2014) Geophysical exploration of an active pockmark field in the Bay of Concarneau, southern Brittany, and implications for resident suspension-feeders. Geo-Mar Lett 34:215-230

Blott SJ, Pye K (2001) GRADISTAT: a grain size distribution and statistics package for the analysis of unconsolidated sediments. Earth Surf Process Landf 26:1237-1248

Borowski WS, Paull CK, Ussler W (1996) Marine pore-water sulphate profiles indicate in situ methane flux from underlying gas hydrate. Geology 24:655-658

> Brissac T, Rodrigues CF, Gros O (2011) Characterization of bacterial symbioses in Myrtea sp. (Bivalvia: Lucinidae) and Thyasira sp. (Bivalvia: Thyasiridae) from a cold seep in the eastern Mediterranean. Mar Ecol 32:198-210

> Brothers LL, Kelley JT, Belknap DF, Barnhardt WA, Andrews BD, Maynard ML (2011) More than a century of bathymetric observations and present-day shallow sediment characterization in Belfast Bay, Maine, USA: implications for pockmark field longevity. Geo-Mar Lett $31: 237-248$

> Callaway R, Desroy N, Dubois S, Fournier J and others (2010) Ephemeral bio-engineers or reef-building polychaetes: How stable are aggregations of the tube worm Lanice conchilega (Pallas, 1766)? Integr Comp Biol 50:237-250

Clarke KR, Gorley RN (2006) PRIMER v6: user manual/ tutorial. PRIMER-E, Plymouth

> Cline JD (1969) Spectrophotometric determinations of hydrogen sulfide in natural waters. Limnol Oceanogr 14:454-458

> Dando PR, Southward AJ (1986) Chemoautotrophy in bivalve molluscs of the genus Thyasira. J Mar Biol Assoc UK 66:915-929

> Dando PR, Austen MC, Burke RA Jr, Kendall MA and others (1991) Ecology of a North Sea pockmark with an active methane seep. Mar Ecol Prog Ser 70:49-63

Dean WE (1974) Determination of carbonate and organic matter in calcareous sediments and sedimentary rocks by loss on ignition: comparison with other methods. J Sediment Petrol 44:242-248

> Decker C, Morineaux M, van Gaever S, Caprais JC, Lichtschlag A and others (2012) Habitat heterogeneity influences cold-seep macrofaunal communities within and among seeps along the Norwegian margin. Part 1: macrofaunal community structure. Mar Ecol 33:205-230

> Dormann CF, Elith J, Bacher S, Buchmann C, Carl G and others (2013) Collinearity: a review of methods to deal with it and a simulation study evaluating their performance. Ecography 36:27-46

> Ehrhold A, Hamon D, Guillaumont B (2006) The REBENT monitoring network, a spatially integrated, acoustic approach to surveying nearshore macrobenthic habitats: application to the Bay of Concarneau (South Brittany, France). ICES J Mar Sci 63:1604-1615

Fader GBJ (1991) Gas-related sedimentary features from the eastern Canadian continental shelf. Cont Shelf Res 11:1123-1153

Fonselius SH (1983) Determination of hydrogen sulfide. In: Grasshoff K, Ehrhardt M, Kremling K (eds) Methods of seawater analysis. Verlag Chemie, Weinheim, p 73-84

Gafeira J, Long D, Diaz-Doce D (2013) Semi-automated characterisation of seabed pockmarks in the central North Sea. Near Surf Geophys 10:303-315

Garcia-Gil S, Vilas F, Garcia-Garcia A (2002) Shallow gas features in incised-valley fills (Ria de Vigo, NW Spain): a case study. Cont Shelf Res 22:2303-2315

Göransson P (2002) Petersen's benthic macrofauna stations revisited in the Oresund area (southern Sweden) and species composition in the 1990s - signs of decreased biological variation. Sarsia 87:263-280

> Gray JS (2000) The measurement of marine species diversity, with an application to the benthic fauna of the Norwegian continental shelf. J Exp Mar Biol Ecol 250:23-49

Hammer Ø, Webb KE, Depreiter D (2009) Numerical simulation of upwelling currents in pockmarks, and data from the inner Oslofjord, Norway. Geo-Mar Lett 29:269-275

Hill MO (1973) Diversity and evenness: a unifying notation and its consequences. Ecology 54:427-432

Hovland M (2005) Pockmark-associated coral reefs at the Kristin field off mid-Norway. In: Freiwald A, Roberts JM (eds) Cold-water corals and ecosystems. SpringerVerlag, Berlin, p 623-632

Hovland M, Judd AG (1988) Seabed pockmarks and seepages: impact on geology, biology and the marine environment. Graham \& Trotman, London

> Hovland M, Gardner JV, Judd AG (2002) The significance of pockmarks to understanding fluid flow processes and geohazards. Geofluids 2:127-136

Hovland M, Heggland R, De Vries MH, Tjelta TI (2010) Unitpockmarks and their potential significance for predicting fluid flow. Mar Pet Geol 27:1190-1199

Kelley JT, Dickson SM, Belknap DF (1994) Giant sea-bed pockmarks: evidence for gas escape from Belfast Bay, Maine. Geology 22:59-62

King LH, MacLean B (1970) Pockmarks on the Scotian Shelf. Geol Soc Am Bull 81:3141-3148

Lapham LL, Chanton JP, Martens CS, Sleeper K, Woolsey SR (2008) Microbial activity in surficial sediments overlying acoustic wipeout zones at a Gulf of Mexico cold seep. Geochem Geophys Geosyst 9:1-17, doi:10.1029/2008 GC001944

Larsen PF (2005) Biodiversity and observations of macrobenthos of Cobscook Bay, Maine. In: Percy JA, Evans AJ, Wells PG, Rolston SJ (eds) The changing Bay of Fundy: beyond 400 years. Proc 6th Bay of Fundy Workshop, Cornwallis, Nova Scotia. Environment Canada - Atlantic Region, Occasional Report No 23, Dartmouth, NS and Sackville, p 353-417 
Legendre P, Anderson MJ (1999) Distance-based redundancy analysis: testing multispecies responses in multifactorial ecological experiments. Ecol Monogr 69:1-24

Lorenzen CJ (1967) Determination of chlorophyll and phaeopigment spectrophotometric equations. Limnol Oceanogr 12:343-346

Menot L, Galeron J, Olu K, Caprais JC, Crassous P and others (2010) Spatial heterogeneity of macrofaunal communities in and near a giant pockmark area in the deep Gulf of Guinea. Mar Ecol 31:78-93

Myers AA, Rigolet C, Thiebaut E, Dubois SF (2012) A new species of amphipod, Photis inornatus sp nov (Corophiidea, Photidae) from a 'Haploops community' in Brittany. Zootaxa 3236:55-61

Nickel JC, di Primio R, Mangelsdorf K, Stoddart D, Kallmeyer J (2012) Characterization of microbial activity in pockmark fields of the SW-Barents Sea. Mar Geol 332-334:152-162

Olu K, Caprais JC, Galeron J, Causse R and others (2009) Influence of seep emission on the non-symbiont-bearing fauna and vagrant species at an active giant pockmark in the Gulf of Guinea (Congo-Angola margin). Deep-Sea Res II 56:2380-2393

Olu-Le Roy K, Caprais JC, Fifis A, Fabri MC and others (2007) Cold-seep assemblages on a giant pockmark off West Africa: spatial patterns and environmental control. Mar Ecol 28:115-130

Pau M, Hammer $\varnothing$ (2013) Sediment mapping and long-term monitoring of currents and sediment fluxes in pockmarks in the Oslofjord, Norway. Mar Geol 346:262-273

Pilcher R, Argent J (2007) Mega-pockmarks and linear pockmark trains on the West African continental margin. Mar Geol 244:15-32

Rigolet C, Le Souchu P, Caisey X, Dubois SF (2011) Group sweeping: feeding activity and filtration rate in the tubiculous amphipod Haploops nirae (Kaim-Malka, 1976). J Exp Mar Biol Ecol 406:29-37

Rigolet C, Dubois SF, Droual G, Caisey X, Thiébaut E (2012) Life history and secondary production of the amphipod Haploops nirae (Kaim-Malka, 1976) in the Bay of Concarneau (South Brittany). Estuar Coast Shelf Sci 113:259-271

Rigolet C, Dubois SF, Thiébaut E (2014a) Benthic control

Editorial responsibility: Erik Kristensen, Odense, Denmark freaks: effects of the tubiculous amphipod Haploops nirae on the specific diversity and functional structure of benthic communities. J Sea Res 85:413-427

Rigolet C, Thiébaut E, Dubois SF (2014b) Food web structures of subtidal benthic muddy habitats: evidence of microphytobenthos contribution supported by an engineer species. Mar Ecol Prog Ser 500:25-41

Sarradin PM, Caprais JC (1996) Analysis of dissolved gases by headspace sampling, gas chromatography with columns and detectors commutation. Preliminary results. Anal Commun 33:371-373

Shotbolt L (2010) Pore water sampling from lake and estuary sediments using Rhizon samplers. J Paleolimnol 44: 695-700

Sims JG, Moore DW (1995) Risk of pore water hydrogen sulfide toxicity in dredged material bioassays. Miscellaneous paper D-95-4, US Army Corps of Engineers Waterways Experiment Station, Vicksburg, MS

Sorbe JC, Frutos I, Aguirrezsabalaga F (2010) The benthic fauna of slope pockmarks from the Kostarrenkala area (Capbreton canyon, SE Bay of Biscay). Munibe 58:85-98

- Webb KE, Barnes DKA, Planke S (2009a) Pockmarks: refuges for marine benthic biodiversity. Limnol Oceanogr 54:1776-1788

> Webb KE, Barnes DKA, Gray JS (2009b) Benthic ecology of pockmarks in the Inner Oslofjord, Norway. Mar Ecol Prog Ser 387:15-25

Webb KE, Hammer Ø, Lepland A, Gray JS (2009c) Pockmarks in the Inner Oslofjord, Norway. Geo-Mar Lett 29:111-124

Whittaker RH (1972) Evolution and measurement of species diversity. Taxon 21:213-251

> Wildish DL, Dickinson JJ (1982) A new species of Haploops (Amphipoda, Ampeliscidae) from the Bay of Fundy. Can J Zool 60:962-967

Wildish DJ, Akagi HM, McKeown DL, Pohle GW (2008) Pockmarks influence benthic communities in Passamaquoddy Bay, Bay of Fundy, Canada. Mar Ecol Prog Ser 357:51-66

- Zeppilli D, Canals M, Danovaro R (2012) Pockmarks enhance deep-sea benthic biodiversity: a case study in the western Mediterranean Sea. Divers Distrib 18: 832-846

Submitted: October 6, 2014; Accepted: March 31, 2015 Proofs received from author(s): May 19, 2015 